\title{
Rare Metals in Kuzbass Ash and Slag Wastes: Prospects of Extraction
}

\author{
Cherkasova Tatyana \\ T.F. Gorbachev Kuzbass State \\ Technical University \\ Kemerovo, Russian Federation \\ ctg.htnv@kuzstu.ru \\ Bobrovnikova Alyona \\ T.F. Gorbachev Kuzbass State \\ Technical University \\ Kemerovo, Russian Federation \\ baa.htnv@kuzstu.ru
}

\author{
Cherkasova Elizaveta \\ T.F. Gorbachev Kuzbass State \\ Technical University \\ Kemerovo, Russian Federation \\ chev.htnv@kuzstu.ru
}

\author{
Tikhomirova Anastasia \\ T.F. Gorbachev Kuzbass State \\ Technical University \\ Kemerovo, Russian Federation \\ tav.htnv@kuzstu.ru
}

\begin{abstract}
Kuznetsk coal basin is one of the largest and most promising basins of the Russian Federation. Deposits of Kuzbass coal are complex ore-coal deposits, containing industrial concentrations of goal, platinum, rare metals in coals, waste coal and bottom ash waste, the extraction of which creates products with high additional coast. In this paper the composition of bottom ash waste (Kemerovo, LeninskKuznetsk, Mezhdurechensk) and methods to extract valuable components from them and the main areas to use them are given. The incentives, allowing ash disposal areas of power plants to be put into production as quick as possible, because they can contain significant stocks of valuable rare, dispersed and rare-earth elements, are justified.
\end{abstract}

Keywords-rare, dispersed and rare-earth elements, coal, ash, slag, extraction

\section{INTRODUCTION}

Coal, being one of the most exploited natural energy carriers, is now more often simply burned, at best, before burning, it is subjected to simple mechanical preparation. In open pit mining, an average of four tons of overburden is removed, in underground mining - $200-300 \mathrm{~kg}$ of waste rock and $200-300 \mathrm{~kg}$ of preparation waste are produced to excavate one ton of coal. Taking into account the average ash content of Kuzbass coal, 100-150 kg of ash and slag can be added to these volumes. The increased requirements for the environmental safety of enterprises working on feed coal necessitate a comprehensive evaluation. Ensuring the storage of 1 ton of ash and slag waste costs the state $\$ 70-100$ per year. Therefore, it is necessary to consider coal as a complex raw material, which contains valuable chemical elements, the extraction of which creates products with high added value (Figure 1, Table 1).

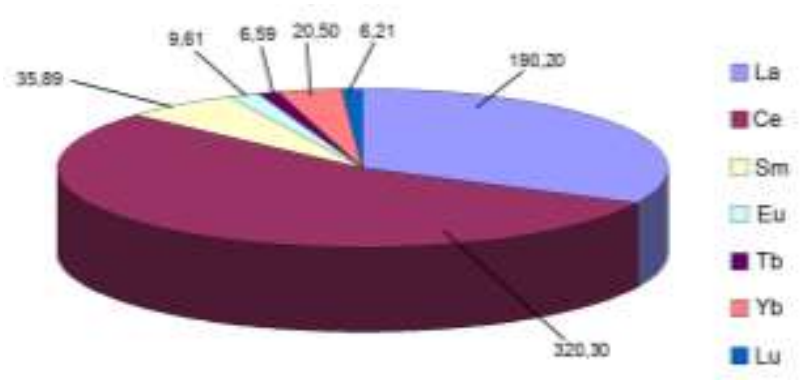

Fig. 1. Rare earth element concentrations in Kuzbass coal, g/t

TABLE I. CONTENT OF RARE EARTH ELEMENTS IN COAL OF DIFFERENT GEOLOGICAL AND INDUSTRIAL AREAS OF KUZBASS REGION G/T

\begin{tabular}{|l|c|c|c|c|c|c|c|}
\hline $\begin{array}{c}\text { geological } \\
\begin{array}{c}\text { and } \\
\text { industrial } \\
\text { area }\end{array}\end{array}$ & $\boldsymbol{L a}$ & $\boldsymbol{C e}$ & $\boldsymbol{S m}$ & $\boldsymbol{E u}$ & $\boldsymbol{T b}$ & $\boldsymbol{Y b}$ & $\boldsymbol{L u}$ \\
\cline { 2 - 9 } & & & & & & & \\
\hline Anzhersky & 1.8 & 3.9 & 0.7 & 0.1 & 0.2 & 0.35 & 0.15 \\
\hline Aralichevsky & 17.6 & 29.8 & 3.05 & 1.31 & 0.58 & 1.78 & 0.38 \\
\hline Baydaevsky & 18.3 & 28.2 & 2.9 & 1.03 & 0.53 & 2.1 & 0.41 \\
\hline Bachatskij & 24.5 & 12.7 & 3.42 & 1.18 & 0.15 & 1.68 & 0.25 \\
\hline $\begin{array}{l}\text { Bunguro- } \\
\text { Chumyshsky }\end{array}$ & 13.9 & 25.6 & 2.37 & 0.65 & 0.37 & 0.89 & 0.39 \\
\hline Kemerovsky & 9.9 & 23.9 & 2.33 & 0.60 & 0.56 & 1.06 & 0.27 \\
\hline Kondomsky & 16.8 & 26.2 & 3.23 & 0.93 & 0.99 & 2.19 & 0.63 \\
\hline Leninsky & 7.9 & 17.7 & 1.33 & 0.33 & 0.2 & 1.13 & 0.33 \\
\hline Mrassky & 24.7 & 37.9 & 2.94 & 0.78 & 0.58 & 3.02 & 2.09 \\
\hline Osinnikovsky & 8.0 & 15.8 & 2.05 & 0.42 & 1.02 & 0.8 & 0.33 \\
\hline Prokopevsky & 8.4 & 14.3 & 1.41 & 0.31 & 0.19 & 1.57 & 0.26 \\
\hline Tom-Usinsky & 12.2 & 22.6 & 2.5 & 0.41 & 0.75 & 1.37 & 0.28 \\
\hline Uskatsky & 12.6 & 38.8 & 5.1 & 0.87 & - & 1.1 & - \\
\hline $\begin{array}{l}\text { Average by } \\
\text { area }\end{array}$ & 13.6 & 22.9 & 2.56 & 0.69 & 0.47 & 1.46 & 0.44 \\
\hline
\end{tabular}

Coal ash-and-slag masses are independent ore deposits located on the surface and do not require expenditures for their miming. Kuzbass coals have a large number of sites containing industrially significant concentrations of rare, dispersed and rare-earth metals. There are slurry dumps of Kuzbass coal processing plant which are completely unexplored for metals, including rare and dispersed. To involve waste into secondary processing, their 
comprehensive exploration and analysis for the stocks of useful components is required. The development of highly selective technologies for the isolation of rare, dispersed and rare-earth elements (REE) from all possible sources, as well as the creation of new functional materials on their basis, are urgent tasks, both economically and environmentally.

Rare, dispersed and rare-earth elements are the necessary resource for the creation and development of modern hightech industries; and in accordance with the requirements of scientific and technological progress in the world, the steady increase of production, consumption, and, consequently REE value a hundredfold, they are much more valuable fuel than coal.

The profitability of coal processing waste will be higher if not single elements are extracted, but their complex, especially including the most expensive rare, rare-earth and noble metals, especially since the explored reserves of Kuznetsk coal contain more than 55 elements of Mendeleev's Periodic Table - from lithium to uranium.

Attractive for practitioners are data on metals that have traditionally high and stable demand in the world market, first of all, for example, titanium, whose content reaches 1$14 \%$ per ton, niobium, its content in Kuzbass coal ash reaches one and more than a kilogram per ton. The content of $\mathrm{RE}$ in Kuzbass coal of is 1-2 orders of magnitude lower than in REE minerals (monazite: 264-280 g/t, loparite: 112-180 $\mathrm{g} / \mathrm{t})$, it sharply increases in ash [1-13].

\section{EXPERIMENTAL RESEARCH METHODS}

The objects of the study were fly ashes from coal burning (Kemerovo, Leninsk-Kuznetskiy, Mezhdurechensk).

Samples of ash for further processing were used without additional grinding.

The analysis of the ashes was carried out by the method of inductively coupled plasma optical emission spectroscopy on the iCAP 6500DIO spectrometer and consisted of several stages.

For solid sampling: a $0.1 \mathrm{~g}$ ash sample was selected by quartering. The same amount of coupling agent - polyvinyl alcohol - was weighed. Both samples (quantitatively transferred) were co-abraded in an agate mortar to a constant shade of color. Then the resulting mixture was poured into a mold, in which was pressed into a compact sample at a pressure of 5 tons $/ \mathrm{cm}^{2}$. The resulting tablets were placed in the chamber of the UP 266 MAQCRO laser sampler, purged with argon, which was sent into the flame of the spectrometer automation. A "solid-gas" aerosol entered the source of atomization.

For solid extracting: the ash was dried to constant weight, then placed in a measuring tube and poured with royal vodka up to graduation line of $50 \mathrm{ml}$. The resulting heterogeneous mixtures were incubated in sealed tubes in special Hotblock system for acid decomposition of samples. The extraction was carried out for 8 hours at $95^{\circ} \mathrm{C}$. In closed vessels, the pressure was increased. Then the vessels cooled to room temperature until the morning of the next working day, the extract was separated quantitatively from the sediment, as far as possible, diluted to the desired volume (according to the regulated concentrations of background components). The resulting solution was analyzed. A "liquid-gas" aerosol is delivered to the atomization source by means of concentric atomizer, a atomizing chamber and a peristaltic pump. Analytic lines of the determined elements were selected according to the principle of freedom from spectral and matrix interference.

Leaching of the ashes was carried out by solutions of sulfuric acid of various concentrations upon heating heating to $65-95^{\circ} \mathrm{C}$ while stirring every 15 minutes for 3 hours, followed by settling for 5 days. Then the samples were flotated.

Adsorption-bubble methods of separation and isolation of components (foam and foamless) in comparison with hydrometallurgical schemes for processing raw materials, which require high costs of reagents and energy, are more promising. Ionic flotation is just such a method. Ion flotation refers to processes based on sorption of the products of the interaction of a surfactant (surfactant) with ions of inorganic compounds at the surface of the "liquid-gas" phases. The method is suitable for extracting substances from solutions with a concentration of up to one hundred million mole per liter. Ion flotation differs from other known extraction methods - extraction and sorption - by selectivity, simplicity, high speed, efficiency even at low component concentrations.

We used ionic flotation to extract rare, dispersed and rare earth elements by various types of surfactants from the products of sulfuric acid treatment of ashes after their magnetic separation.

The flotation was carried out in a laboratory flotation machine FL-240 for 5, 10, 15 minutes, at $\mathrm{pH}$ 7.5-8.5 in 0.5 increments, the ratio of organic and aqueous phases was $(1 \div 20)-(1 \div 40)$. In the processes, isooctyl alcohol (2ethylhexanol, $\mathrm{C}_{8} \mathrm{H}_{18} \mathrm{O}$ ) and sodium dodecyl sulfate $\left(\mathrm{C}_{12} \mathrm{H}_{25} \mathrm{SO}_{4} \mathrm{Na}\right)$ were used [14-18].

\section{RESULTS AND DISCUSSION}

The results of analysis of the ashes are given in Tables 2-7.

TABLE II. A SAMPLE OF COAL ASH (FLY ASH FROM THE KEMEROVO THERMAL POWER STATION)

\begin{tabular}{|c|c|c|c|}
\hline \multicolumn{2}{|c|}{ Direct analysis - laser sampling } & \multicolumn{2}{c|}{ Analysis of the extract } \\
\hline Element & Content, \% & Element & Content, \% \\
\hline $\mathrm{SiO}_{2}$ & $63.5 \pm 0.1$ & $\mathrm{Sr}$ & $1.1 \cdot 10^{-1}$ \\
\hline $\mathrm{TiO}_{2}$ & $0.64 \pm 0.03$ & $\mathrm{Zr}$ & $2.3 \cdot 10^{-4}$ \\
\hline $\mathrm{Al}_{2} \mathrm{O}_{3}$ & $23.5 \pm 0.1$ & $\mathrm{Nb}$ & $7 \cdot 10^{-4}$ \\
\hline $\mathrm{Fe}_{2} \mathrm{O}_{3}$ & $3.3 \pm 0.6$ & $\mathrm{Ga}$ & $9 \cdot 10^{-4}$ \\
\hline $\mathrm{MnO}$ & $0.018 \pm 0.001$ & $\mathrm{Y}$ & $1.4 \cdot 10^{-3}$ \\
\hline $\mathrm{CaO}$ & $5.3 \pm 0.3$ & $\mathrm{Mo}$ & $8.7 \cdot 10^{-4}$ \\
\hline $\mathrm{MgO}$ & $0.86 \pm 0.08$ & $\mathrm{Au}$ & $1.2 \cdot 10^{-4}$ \\
\hline $\mathrm{Na}_{2} \mathrm{O}$ & $0.97 \pm 0.06$ & $\mathrm{Ag}$ & - \\
\hline $\mathrm{K}_{2} \mathrm{O}$ & $1.1 \pm 0.1$ & $\mathrm{Eu}$ & $6.8 \cdot 10^{-5}$ \\
\hline $\mathrm{P}_{2} \mathrm{O}_{5}$ & $0.29 \pm 0.06$ & $\mathrm{La}$ & $1.9 \cdot 10^{-3}$ \\
\hline $\mathrm{Ba}$ & $0.28 \pm 0.06$ & $\mathrm{Pr}$ & $7 \cdot 10^{-4}$ \\
\hline- & - & $\mathrm{Sm}$ & $1.5 \cdot 10^{-4}$ \\
\hline- & - & $\mathrm{V}$ & $5.3 \cdot 10^{-3}$ \\
\hline
\end{tabular}

TABLE III. THE CONTENT OF RARE AND RARE-EARTH ELEMENTS IN FLY ASH FROM THE KEMEROVO THERMAL POWER STATION

\begin{tabular}{|c|c|c|}
\hline \multirow{2}{*}{ Element } & \multicolumn{2}{|c|}{ Content } \\
\cline { 2 - 3 } & $\boldsymbol{\%}$ & $\boldsymbol{g} / \boldsymbol{t}$ \\
\hline $\mathrm{Sr}$ & $1.1 \cdot 10^{-2}$ & 110.00 \\
\hline $\mathrm{Zr}$ & $2.3 \cdot 10^{-4}$ & 2.30 \\
\hline $\mathrm{Nb}$ & $7.0 \cdot 10^{-4}$ & 7.00 \\
\hline $\mathrm{Ga}$ & $9.0 \cdot 10^{-4}$ & 9.00 \\
\hline $\mathrm{Mo}$ & $8.7 \cdot 10^{-4}$ & 8.70 \\
\hline
\end{tabular}




\begin{tabular}{|c|c|c|}
\hline $\mathrm{Au}$ & $1.2 \cdot 10^{-4}$ & 1.20 \\
\hline $\mathrm{Ag}$ & - & - \\
\hline $\mathrm{V}$ & $5.3 \cdot 10^{-3}$ & 53.00 \\
\hline REE: & $1.4 \cdot 10^{-3}$ & \\
\hline \multicolumn{3}{|c|}{} \\
\hline $\mathrm{Y}$ & 14.00 & 0.68 \\
\hline $\mathrm{Eu}$ & $6.8 \cdot 10^{-5}$ & 19.00 \\
\hline $\mathrm{La}$ & $1.9 \cdot 10^{-3}$ & 7.00 \\
\hline $\mathrm{Pr}$ & $7.0 \cdot 10^{-4}$ & \\
\hline $\mathrm{Sm}$ &
\end{tabular}

TABLE IV. A SAMPLE OF COAL ASH (LENINSK-KUZNETSKIY)

\begin{tabular}{|c|c|c|c|}
\hline \multicolumn{2}{|c|}{ Direct analysis - laser sampling } & \multicolumn{2}{c|}{ Analysis of the extract } \\
\hline Element & Content, \% & Element & Content, \% \\
\hline $\mathrm{SiO}_{2}$ & $41.4 \pm 0.3$ & $\mathrm{Sr}$ & $2.3 \cdot 10^{-1}$ \\
\hline $\mathrm{TiO}_{2}$ & $1.11 \pm 0.01$ & $\mathrm{Zr}$ & $2.5 \cdot 10^{-3}$ \\
\hline $\mathrm{Al}_{2} \mathrm{O}_{3}$ & $31.5 \pm 0.1$ & $\mathrm{Nb}$ & $9.6 \cdot 10^{-4}$ \\
\hline $\mathrm{Fe}_{2} \mathrm{O}_{3}$ & $8.1 \pm 0.1$ & $\mathrm{Ga}$ & $2.1 \cdot 10^{-3}$ \\
\hline $\mathrm{MnO}$ & $0.017 \pm 0.001$ & $\mathrm{Y}$ & $3.3 \cdot 10^{-3}$ \\
\hline $\mathrm{CaO}$ & $9.2 \pm 0.6$ & $\mathrm{Mo}$ & $2.8 \cdot 10^{-3}$ \\
\hline $\mathrm{MgO}$ & $3.1 \pm 0.1$ & $\mathrm{Au}$ & $4.6 \cdot 10^{-4}$ \\
\hline $\mathrm{Na} \mathrm{O}$ & $2.63 \pm 0.06$ & $\mathrm{Ag}$ & - \\
\hline $\mathrm{K}_{2} \mathrm{O}$ & $1.30 \pm 0.03$ & $\mathrm{Eu}$ & $1.9 \cdot 10^{-4}$ \\
\hline $\mathrm{P}_{2} \mathrm{O}_{5}$ & $0.17 \pm 0.01$ & $\mathrm{La}$ & $4.2 \cdot 10^{-3}$ \\
\hline $\mathrm{Ba}$ & $1.14 \pm 0.01$ & $\mathrm{Pr}$ & $1 \cdot 10^{-3}$ \\
\hline- & - & $\mathrm{Sm}$ & $9.9 \cdot 10^{-4}$ \\
\hline- & - & $\mathrm{V}$ & $1 \cdot 10^{-2}$ \\
\hline
\end{tabular}

TABLE V. THE CONTENT OF RARE AND RARE-EARTH ELEMENTS IN THE ASHES (LENINSK-KUZNETSKIY)

\begin{tabular}{|c|c|c|}
\hline \multirow{2}{*}{ Element } & \multicolumn{2}{|c|}{ Content } \\
\cline { 2 - 3 } & \% & g/t \\
\hline $\mathrm{Sr}$ & $4.3 \cdot 10^{-1}$ & 230.00 \\
\hline $\mathrm{Zr}$ & $2.5 \cdot 10^{3}$ & 9.40 \\
\hline $\mathrm{Nb}$ & $9.6 \cdot 10^{-4}$ & 21.00 \\
\hline $\mathrm{Ga}$ & $2.1 \cdot 10^{-3}$ & 28.00 \\
\hline $\mathrm{Mo}$ & $2.8 \cdot 10^{-3}$ & 4.60 \\
\hline $\mathrm{Au}$ & $4.6 \cdot 10^{-4}$ & - \\
\hline $\mathrm{Ag}$ & - & 100.00 \\
\hline $\mathrm{V}$ & $1.2 \cdot 10^{-2}$ & 33.00 \\
\hline $\mathrm{REE}: \mathrm{r}$ & 1.90 \\
\hline $\mathrm{Y}$ & $3.3 \cdot 10^{-3}$ & 42.00 \\
\hline $\mathrm{Eu}$ & $1.9 \cdot 10^{-4}$ & 10.00 \\
\hline $\mathrm{La}$ & $4.2 \cdot 10^{-3}$ & 9.90 \\
\hline $\mathrm{Pr}$ & $1.0 \cdot 10^{-3}$ & \\
\hline $\mathrm{Sm}$ & $9.9 \cdot 10^{-4}$ & \\
\hline
\end{tabular}

TABLE VI. A SAMPLE OF COAL ASH (MEZHDURECHENSK)

\begin{tabular}{|c|c|c|c|}
\hline \multicolumn{2}{|c|}{ Direct analysis - laser sampling } & \multicolumn{2}{c|}{ Analysis of the extract } \\
\hline Element & Content, \% & Element & Content, \% \\
\hline $\mathrm{SiO}_{2}$ & $48.7 \pm 0,1$ & $\mathrm{Sr}$ & $1.1 \cdot 10^{-1}$ \\
\hline $\mathrm{TiO}_{2}$ & $0.93 \pm 0,03$ & $\mathrm{Zr}$ & $2 \cdot 10^{-1}$ \\
\hline $\mathrm{Al}_{2} \mathrm{O}_{3}$ & $37.9 \pm 0,1$ & $\mathrm{Nb}$ & $2.6 \cdot 10^{-3}$ \\
\hline $\mathrm{Fe}_{2} \mathrm{O}_{3}$ & $4.3 \pm 0,2$ & $\mathrm{Ga}$ & $3.2 \cdot 10^{-3}$ \\
\hline $\mathrm{MnO}$ & $0.11 \pm 0,01$ & $\mathrm{Y}$ & $5 \cdot 10^{-3}$ \\
\hline $\mathrm{CaO}$ & $2.1 \pm 0,1$ & $\mathrm{Mo}$ & $1.4 \cdot 10^{-3}$ \\
\hline $\mathrm{MgO}$ & $0.38 \pm 0,03$ & $\mathrm{Au}$ & - \\
\hline $\mathrm{Na}_{2} \mathrm{O}$ & $1.8 \pm 0,1$ & $\mathrm{Ag}$ & $6 \cdot 10^{-5}$ \\
\hline $\mathrm{K}_{2} \mathrm{O}$ & $0.53 \pm 0,03$ & $\mathrm{Eu}$ & $6 \cdot 10^{-5}$ \\
\hline $\mathrm{P}_{2} \mathrm{O}_{5}$ & $2.6 \pm 0,2$ & $\mathrm{La}$ & $4 \cdot 10^{-3}$ \\
\hline $\mathrm{Ba}$ & $0.21 \pm 0,01$ & $\mathrm{Pr}$ & $5 \cdot 10^{-4}$ \\
\hline- & - & $\mathrm{Nd}$ & $1 \cdot 10^{-3}$ \\
\hline- & - & $\mathrm{V}$ & $5.6 \cdot 10^{-3}$ \\
\hline
\end{tabular}

TABLE VII. THE CONTENT OF RARE, DISPERSED AND RARE-EARTH ELEMENTS IN ASH (MEZHDURECHENSK)

\begin{tabular}{|c|c|c|}
\hline \multirow{2}{*}{ Element } & \multicolumn{2}{|c|}{ Content } \\
\cline { 2 - 3 } & $\boldsymbol{\%}$ & $\boldsymbol{g} / \boldsymbol{t}$ \\
\hline $\mathrm{Sr}$ & $1.1 \cdot 10^{-1}$ & 1100.00 \\
\hline $\mathrm{Zr}$ & $2.0 \cdot 10^{-1}$ & 2000.00 \\
\hline $\mathrm{Nb}$ & $2.6 \cdot 10^{-3}$ & 26.00 \\
\hline $\mathrm{Ga}$ & $3.2 \cdot 10^{-3}$ & 32.00 \\
\hline
\end{tabular}

\begin{tabular}{|c|c|c|}
\hline Mo & $1.4 \cdot 10^{-3}$ & 14.00 \\
\hline $\mathrm{Au}$ & - & - \\
\hline $\mathrm{Ag}$ & $6.0 \cdot 10^{-5}$ & 0.60 \\
\hline $\mathrm{V}$ & $5.6 \cdot 10^{-3}$ & 56.00 \\
\hline $\mathrm{REE}: \mathrm{I}$ & 50.00 \\
\hline \multicolumn{3}{|l|}{} \\
\hline $\mathrm{Y}$ & $5.0 \cdot 10^{-3}$ & 0.60 \\
\hline $\mathrm{La}$ & $6.0 \cdot 10^{-5}$ & 40.00 \\
\hline $\mathrm{Pr}$ & $4.0 \cdot 10^{-3}$ & 5.00 \\
\hline $\mathrm{Nd}$ & $5.0 \cdot 10^{-4}$ & 10.00 \\
\hline
\end{tabular}

Obviously, it is necessary to separate rare metals, first of all from silicon, aluminum and iron oxides and their subsequent concentration.

The process proceeds according to the reaction:

$$
\mathrm{Me}^{\mathrm{n}+}+\mathrm{nC}_{12} \mathrm{H}_{25} \mathrm{SO}_{4} \mathrm{Na}=\mathrm{Me}\left(\mathrm{C}_{12} \mathrm{H}_{25} \mathrm{SO}_{4}\right) \mathrm{n}+\mathrm{nNa}^{+}
$$

In the solution, the metal cations form strong hydroxycomplexes with sodium dodecyl sulfate, which, due to the hydrophobicity of the alkyl radicals, transfer to the organic phase-isooctyl alcohol.

The foam products obtained as a result of selective ion flotation were collected, dried and calcined at $1000^{\circ} \mathrm{C}$ for 2 hours.

The obtained concentrates of the target products, suitable for further processing - separation of elements (Table 8), are light gray or yellowish fine powders that contain oxides: $\mathrm{SrO}$, $\mathrm{ZrO}_{2}, \mathrm{VO}_{2}, \mathrm{Nb}_{2} \mathrm{O}_{5}, \mathrm{Ga}_{2} \mathrm{O}_{3}, \mathrm{MoO}_{2}, \mathrm{Ln}_{2} \mathrm{O}_{3}$. In water, only strontium oxide is dissolved. When interacting with acids $\left(\mathrm{HCl}, \mathrm{HNO}_{3}\right)$ most of the powders $\left(\mathrm{SrO}, \mathrm{VO}_{2}, \mathrm{Ga}_{2} \mathrm{O}_{3}, \mathrm{Ln}_{2} \mathrm{O}_{3}\right)$ dissolve, oxides of vanadium, gallium, molybdenum, niobium dissolve when reacting with alkalis. Different solubility can be used in the separation of components. Virtually all components concentrates are refractory.

TABLE VIII. THE CONTENT OF RARE, DISPERSED RARE-EARTH ELEMENTS IN CONCENTRATES

\begin{tabular}{|c|c|}
\hline Element & concentrate $\mathbf{1}$ content, \% / g/t \\
\hline $\mathrm{Sr}$ & $2.7 \cdot 10^{-1} / 2700$ \\
\hline $\mathrm{Zr}$ & $1 \cdot 10^{-1} / 100$ \\
\hline $\mathrm{Nb}$ & $9 \cdot 10^{-3} / 90$ \\
\hline $\mathrm{Ga}$ & $5 \cdot 10^{-3} / 50$ \\
\hline $\mathrm{Mo}$ & $3 \cdot 10^{-2} / 300$ \\
\hline $\mathrm{V}$ & $2 \cdot 10^{-1} / 2000$ \\
\hline $\mathrm{REE}$ & $8.5 \cdot 10^{-2} / 850$ \\
\hline $\mathrm{Element}$ & concentrate $\mathbf{2}$ content, \% / g/t \\
\hline $\mathrm{Sr}$ & $1.3 \cdot 10^{-1} / 1300$ \\
\hline $\mathrm{Zr}$ & $1.2 \cdot 10^{-1} / 1200$ \\
\hline $\mathrm{Nb}$ & $8.5 \cdot 10^{-3} / 85$ \\
\hline $\mathrm{Ga}$ & $4.8 \cdot 10^{-3} / 48$ \\
\hline $\mathrm{Mo}$ & $2 \cdot 10^{-2} / 200$ \\
\hline $\mathrm{V}$ & $3 \cdot 10^{-1} / 3000$ \\
\hline $\mathrm{REE}$ & $7.7 \cdot 10^{-2} / 770$ \\
\hline
\end{tabular}

\section{CONCLUSIONS}

The results obtained allow concluding that it is possible to extract valuable rare, dispersed and rare-earth elements from coal processing waste in Kuzbass. In addition to obtaining products with high added value, waste processing improves the complex environmental situation in the industrialized region. 


\section{REFERENCES}

[1] B.F. Nifantov, V.P. Potapov, and N.V. Mitina, "Geochemistry and evaluation of the resources of rare-earth and radioactive elements in Kuznetsk coal," Processing prospects. Kemerovo: Institute of Coal and Coal Chemistry of SB of RAS, 2003, 104 p.

[2] V.V. Krapivintseva, "Metal content of Amur River basin coal," Pacific Geology, vol 24(1), 2005, pp. 73-84.

[3] M.D. Skurskiy, "Forecast of rare earth - rare metal - oil-and-gas fields in Kuzbass,” Kemerovo: Kuzbass University Puiblishing, 2005, 627 p.

[4] A.A. Cherepanov, and V.T. Kardash, "Complex processing of ash and slag wastes of thermal power plant. Geology and minerals of the World Ocean," Department of Marine Geology and Sedimentary Ore Formation of the National Academy of Sciences of Ukraine, Kiev, 2009, (2), pp. 98-115.

[5] V.A. Salikhov, "Geological, economic and economic (value) valuation of non-ferrous and rare metals contained in coals and ashand-slag waste of coal," Bulletin of Tomsk State University. Economy, vol. 1(25), 2014, pp. 123-138.

[6] M.I. Gamov, N.V. Granovskaya, and S.V. Levchenko, "Metals in coals," Rostov-on-Don: YuFU, 2012, 45 p.

[7] S.I. Arbuzov, V.V. Yershov, A.A. Potseluev, and L.P. Rikhvanov, "Rare elements in Kuznetsk basin coals," Kemerovo: Kemerovo Printing and Publishing Complex, 1999, 248 p.

[8] S.I. Arbuzov, "Geochemistry of rare elements in Central Siberia coals: thesis for a Doctor's of Science degree in Geology and Mineralogy," Tomsk, 2005, 499 p.

[9] S.I. Polkin, "Processing of ores and placers of rare and precious metals," Moscow: Nedra, 1987, 428 p.
[10] V.A. Salikhov, "Prospects for the development of small knowledge intensive industries (on the example of the Kemerovo region),". Bulletin of KuzSTU, Kemerovo, vol. 4, 2011, pp. 255-258.

[11] S.I. Arbuzov, "Metal content of Siberia coals," Bulletin of TPU, Tomsk, vol 311(1), 2007, pp. 77-83.

[12] Shunsuke Kashiwakura, Yuichi Kumagai, Hiroshi Kubo, and Kazuaki Wagatsuma, "Dissolution of Rare Earth Elements from Coal Fly Ash Particles in a Dilute $\mathrm{H}_{2} \mathrm{SO}_{4}$ Solvent," Open Journal of Physical Chemistry, USA, vol. 3, 2013, pp. 69-75.

[13] Wojciech Franus, Wiatros-Motyka Małgorzata M., Wdowin Magdalena, "Coal fly ash as a resource for rare earth elements," Environmental Science and Pollution Research, vol. 22, 2015, pp. 9464-9474.

[14] Tran X. Phuoc, Ping Wang, and McIntyre Dustin, "Detection of rare earth elements in Powder River Basin sub-bituminous coal ash using laser-induced breakdown spectroscopy (LIBS)," Elsevier. ScienceDirect, vol. 163, 2016, pp. 129-132.

[15] Lange Camila N., Camargo Iara M.C., Figueiredo, Ana Maria G. M. et al, "Brazilian coal fly ash as a potential source of rare earth elements," Journal of Radioanalytical and Nuclear Chemistry, vol. 311, 2017, pp. 1235-1241.

[16] Yu.A. Vershakova, "Extraction of rare-earth elements by the method of ion flotation in the case of nitric acid processing of apatite: thesis for a Csandidate's of Technical Science degree," Apatites, 2003, 80 p.

[17] D.V. Abryutin, and K.A. Streltsov, "Prospects for the use of ionic flotation," Bulletin of higher education institutions. Ferrous Metallurgy, vol. 3, 2013, pp. 3-6.

[18] O.A. Lobacheva, and N.V. Dzhevaga, "The ion flotation of europium (III) and erbium (III)". National Mineral and Raw University "Mining", St.Petersburg, 2016, pp. 106-108. 